\title{
Historic Centers Restoration and Ancient Buildings Energetic Efficiency Improvement
}

\author{
Nicola Santopuoli, Ilaria Pecoraro \\ Sapienza, Università di Roma, Rome, Italy \\ Email: nicola.santopuoli@uniroma1.it, ilaria.pecoraro@tiscali.it
}

Received 25 May 2014; revised 15 August 2014; accepted 15 September 2014

Copyright (C) 2014 by authors and Scientific Research Publishing Inc.

This work is licensed under the Creative Commons Attribution International License (CC BY). http://creativecommons.org/licenses/by/4.0/

c) (i) Open Access

\begin{abstract}
The historical center is a part of the city with specific environmental, architectural and historical values, which emerges from the urban fabric structural continuity. This complex reality requires a comprehensive understanding to determinate the most proper ways to carry out functional transformations and system adaptations, with respect to historical buildings values. Each building must obtain those proper improvements and functional adjustments, also in terms of technology and energetic efficiency. The achievements of a complex interdisciplinary research project on Ceglie Messapica historical center (BR, Italy) are explained. They lead to guidelines for mulation for the historical buildings' critical conservative restoration.
\end{abstract}

\section{Keywords}

Historic Center, Stone Architectures, Conservation, Restoration, Energetic Efficiency

\section{Historic Centers Restoration and Ancient Buildings Energetic Efficiency Improvement}

The historical center is intended as the part of the city with specific environmental, architectural and historical values, which emerges from the urban fabric structural continuity. The city is as an architectural and environmental figuration devoid of absolute formal purity which, however, admits changes and variations possibility. This complex reality requires a comprehensive understanding with attention on buildings, architectural language and cultural taste manifestation.

It's first necessary to recognize historic town characters and connective relationships with the aim to preserve and exploit them through an appropriate preservative operation using the most relevant conservation tools: the principles of restoration [1]. It will be possible to determine the most proper ways to carry out functional transformations and system adaptations, respectful of historical buildings values. 
A commitment to proper respect for history should emerge in the restoration project, with the awareness that buildings use requires the adaptation over time to the needs of people who use it. The modern restoration has faced these issues which are reiterated in the European Charter of the Architectural Heritage and in the Declaration of Amsterdam (1975) on the "integrated conservation", referred to the relations between monument-city and restoration-appropriate functions ${ }^{1}$.

Each building must obtain those proper improvements and functional adjustments, also in terms of technology and energetic efficiency [2]. A new building should satisfy multiple system engineering, energetic and electronicdigital requirements. Today the house is a real "machine for living" in which technological systems are leased to improve the hygrothermal comfort, lighting, sound, water-sewer, through home automation systems which are becoming more complex.

The ancient structures subjected to functional recovery, are also increasingly gain interest by adjustment, substitution and modernization processes of technological systems.

Since the nineties of last century, lighting first and then energetic efficiency improvement have forcefully affected architectural monuments restoration in relation to the importance that they have reached in the construction industry. Simple intervention on the work of art's material is no longer enough, while instead, the building rehabilitation in the functions world is required.

Management systems of lighting, thermo-hygrometric and gaseous functions of rooms have been long time used in important ancient monuments as Leonardo da Vinci's Cenacolo in Milan, Sistine Chapel in Vatican, Domus neroniana's octagonal room, Terme di Diocleziano's planetarium in Rome and Troia Cathedral's crypt in Puglia.

Environmental physics discipline applied to restoration is long time taught at Scuola di Specializzazione in Beni Architettonici e del Paesaggio, "Sapienza” Università di Roma: ancient buildings can respond positively in terms of energetic efficiency, although they're built with traditional materials and technical solutions.

Interdisciplinarity is the main tool to coordinate the various skills required for the study and the interventions design, consistently and exhaustively in agreement with the principle of restoration methodological unity [3].

However, it should be considered that, often, the original use was very different from the new one proposed by the project. It is necessary to reconcile the requirements related to building preservation with those current demanded by the society on comfort. The transformations should be respectful to ancient buildings historical and cultural features and context preservation. These features correct interpretation becomes imperative to identify technical and design solutions in continuity with the existing, and to guarantee the necessary systems adaptation and energetic efficiency improvement [4].

A complex interdisciplinary research project results on Ceglie Messapica historic center (Brindisi, Italy) are explained. Figure 1 shows some pictures of Ceglie Messapica. They lead to guidelines formulation for the critical-conservative restoration of historic buildings surface treatments [5]. The municipal administration involved CITERA (Interdepartmental Center for Landscape, Construction, Restoration, Environment) an interdisciplinary center at “Sapienza”, Università di Roma ${ }^{2}$. A research about the historical-archaeological, technical-constructive, landscape-environmental and energetic-system aspects of historic center is started.

As a part of research project in relation to existing buildings energetic assessment, experimental studies are exploring the possible combined use of thermography and 3D laser scanner survey. Besides, the Computational Fluid Dynamics (CFD) for microclimate variations study into buildings has been carried out in order to optimize natural ventilation or air conditioning systems use.

\section{Buildings Technical-Constructive Characters in Ceglie Messapica Historic Center}

Ceglie Messapica traditional building techniques answer to the same constructive dictates of Salento which,

\footnotetext{
${ }^{1}$ The Venice Charter (1964), art. 5 says: "The conservation of monuments is always facilitated by making use of them for some socially useful purpose. Such use is therefore desirable but it must not change the lay-out or decoration of the building. It is within these limits only that modifications demanded by a change of function should be envisaged and may be permitted”. The European Charter of the Architectural Heritage (1975), art. 7 reads: "Integrated conservation averts these dangers. Integrated conservation is achieved by the application of sensitive restoration techniques and the correct choice of appropriate functions".

${ }^{2}$ The project "Studies, surveys and definition of regulation guidance for Ceglie Messapica colorings and architectural surfaces conservation" has been developed by CITERA (director: prof. ing. Livio de Santoli; scientific responsible: prof. arch. Nicola Santopuoli; arch. Ilaria Pecoraro: PhD and Ostuni freelance architect specialized in monumental restoration). A "Colour Plan" aimed at defining "Guidelines for wall surfaces treatment in Ceglie Messapica historic center” has been prepared in 2012, on municipal administration behalf.
} 


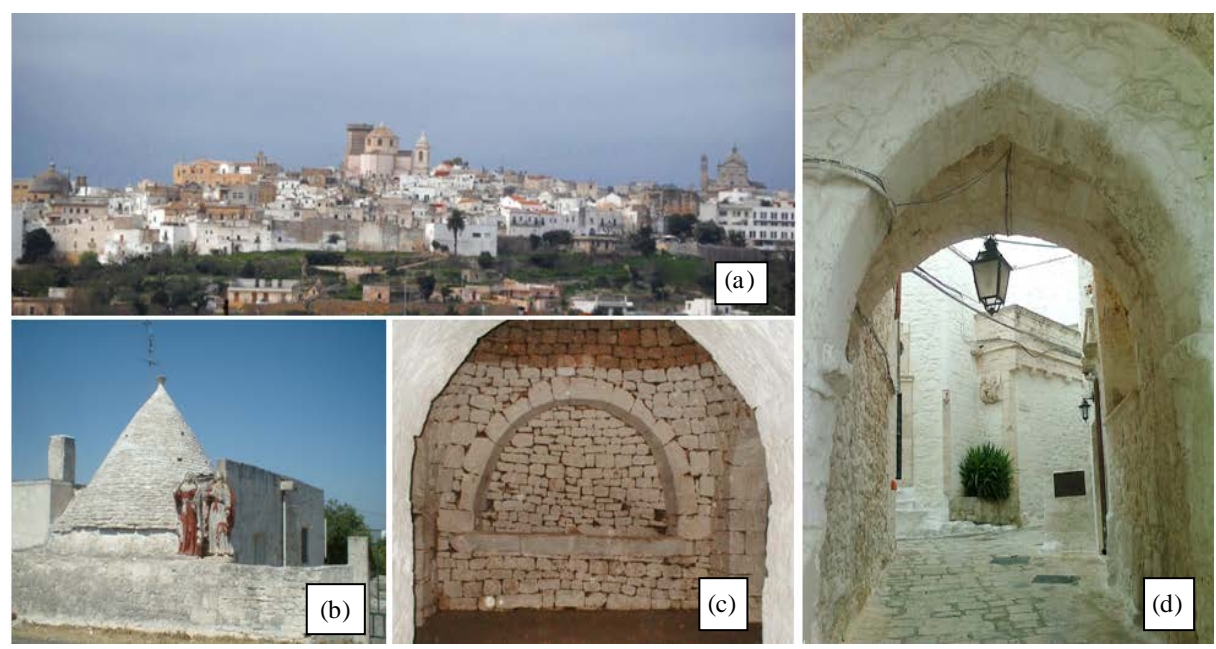

Figure 1. (a) Ceglie Messapica: historic center panoramic view; (b) Itria Valley country: votive statues and "trullo" house, lime finished; (c) Ceglie Messapica: calcareous local stone organized in a horizontal lines dry system; (Pictures: I. Pecoraro, 2012); (d) Ceglie Messapica: urban entrance characterized by thick wall sections, "latte di calce" (milk of lime) finished.

from time, have been treated in many specialized publications ${ }^{3}$. These rules have been adapted to the more compact and durable nature of the local calcareous stone, which is less friable than Lecce rock. From the technical-constructive point of view, modern masonry and vaults are made "a secco" and "a sacco", on not more than three levels above ground, while the vaulted systems used are the Lecce's stellar and barrel types. Large wall sections and high thermal inertia characterize the physical and geometric nature of these simple masonries, founded on the rock. Wall sections contain a core made "a sacco" with irregular fragments, stones and earth. Wall external parts are organized in quite constant horizontal lines of irregular parallelepipedic shape stones with variable height $(22-26 \mathrm{~cm}$ ) in relation to the local quarries of origin. Structural mortar is not used between stone horizontal lines; there is a lean mortar made of lime and stone powder, instead. Both the wall surfaces are plastered with a strongly hydraulic lime mortar called "cazzafitta" and then finished with "latte di calce" (milk of lime) [6], brush applied in many layers and renovated over the centuries. A specialized use of few poor materials is noticed observing constructive technique. Local calcareous stone, lime, earth, marble powder: these all are native raw materials ${ }^{4}$. Ceglie Messapica is located about 300 meters above sea level, on the foothill low Murgia, on the border with Itria Valley to the north-west and the Adriatic territories of Ostuni, Cisternino, San Michele Salentino and Francavilla Fontana. Town oldest part, known as "la Terra", is developed within the messapico-medieval defensive walls, on the top of the hill where the castle and the Matrice church occupy a 5 hectares area. The historic center embraces also areas outside the defensive walls, clinging inside the ancient messapico settlement along the eastern Brindisi side and the western Taranto ridge. The medieval urban fabric, typologically and formally very interesting, is adjacent to the modern districts, extra moenia. These run along the ridge driveways, pedestrian roads and some pre-classical paths. As an important military, political and religious messapico center (Plinio called it Caelium) Ceglie Messapica flourished between IV and III century b.C. Some pieces of Paretone walls, which contained the buildings, is still visible.

Ceglie Messapica history has crossed various stages, from pre-classical eras until today. This is witnessed by exceptional archaeological remains (big walls, "specchie" and necropolis) studied by dott. Cocchiaro, defensive

\footnotetext{
${ }^{3}$ About traditional building techniques: Ilaria Pecoraro, 2003, pp. 51-66; id., in “Arkos”, 6/2004, pp. 52-61; id., 2004, in

http://www.nardinirestauro.it/pubblicazioni atti.asp; id., 2005, pp. 119-132; id., pp. 5-81; id., "Materiali e strutture. Problemi di conservazione”, n.s. II, 3-4/2004, pp. 62-87; id., 2010; www.forumcalce.it; Pecoraro I., 2003, Las bovedas estrelladas del Salento. Una arquitectura a caballo entre la Edad Media y la Edad Moderna, in Mira E., Zaragozà Catalan A. (edite by), "Una arquitectura gòtica mediterrànea", Valencia, Spain, II vol., pp. 51-66; Pecoraro I., 2004, Architetture salentine a conci squadrati dei secoli XV-XVIII. Anomalie e uniformità dimensionali dei conci lapidei in cava e in cantiere, in “Arkos”, n. 6, pp. 52-61.

${ }^{4}$ Fiorani D., Esposito D. (edite by), 2005, Tecniche costruttive dell'edilizia storica. Conoscere per conservare, Roma; Pecoraro I., 2005, Zetetike. Metodi di lettura e problemi di conservazione delle tecniche costruttive in terra d'Otranto, edizione Amici della "A. De Leo", Brindisi, pp. 5-81; Pecoraro I., 2004, Architettura di età moderna in Terra d'Otranto. Tipi murari e meccanismi di collasso, in "Materiali e strutture. Problemi di conservazione”, n.s. II, 3-4/2004, pp. 62-87.
} 
monuments and widespread medieval and modern architectural structures (XIV-XIX) [7]. Some historic center views of the alleys can be seen in Figure 2.

In Ceglie Messapica historic center every building is shaped not only as a row house, mansion, set of units designed to meet residential settlement needs, but also as a memory fragment, irreplaceable piece of urban puzzle that helps to define the whole harmony, expanding the aesthetic uses scope.

This cultural aims chorus, that unites all the city historical buildings, is communicated primarily by surface treatments color of the same architectures [8]. Here the word "color" is not meaning only the paint of the limebased plaster applied by brush on the external wall surfaces but even the presence of furnishings and green public-private elements which can improve or mortify the whole visual enjoyment of the urban landscape built from history [9].

In "Terra" district the minor building is at the center of urban environment scenic organization. Its consistent and uniform appearance is characterized by the lime-based plaster which contrasts the not plastered squared stones facades of the castle and the Matrice church, the most notable monuments. The major value of this architecture called "minor" doesn't come from the stylistic elements which also contribute to embellish certain building expressions. It results, instead, from the attention given to aggregation, melting and building recasting system. All of these, taken together, in addition to meeting the shelter housing need, provide a homogeneous and shared aesthetic answer: private but public wall surfaces contribute with their own morphology and color to the scenic organization of city pieces. This characteristic makes it nice attendance of the urban center, built by anyone, for everyone, shared by everybody with everyone. The same applies to Cisternino, Martina Franca and Ostuni, places for which, in the seventies of last century, it has been talked about urban organization born in relation to a "neighborhood culture": this is pugliese people aptitude for living in groups around courts, lanes and lime whitewashed walls. Facing stone currently covers the major monuments: the castle, Matrice church, other churches and eighteenth-nineteenth century buildings. On the other side, limewash finishing, pigmented or not, veils wall surfaces of minor historic architectures which compose the building fabric base of the whole medieval, modern and first twentieth century historic center.

Historic buildings are characterized by facade elements like "curviedde" (stone rings located on the windows side); small shelves, on the windows side yet; "pontoni” (small discharge arches between parallel walls, realized as antiseismic coverage) [10]; "mignani" (open entrances cover by stairs that wrap around themselves to let coming in a level where women could look out without exposure); small stairs at ground floor; bowers; finely carved stone portals; stone carved support shelves to the balcony; underpasses turned "a volta" or "a lamia", often enriched with frescoed votive aedicule. It's seldom noticed ancient reclaimed materials use.

Between monuments and minor architecture there are middle-classes residential buildings which, without resorting to stylistic connotation, recall their decorative elements: corner shelves use, one of the most recurrent
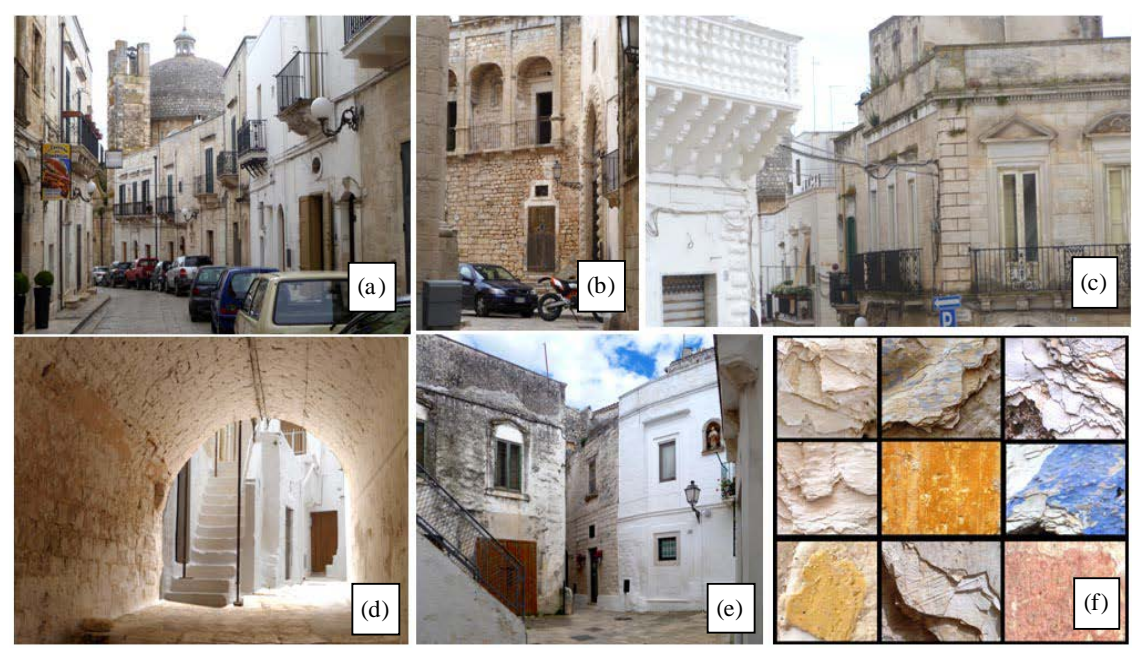

Figure 2. (a), (b), (c), (e) Ceglie Messapica: historic center views of the alleys; (d) Ceglie Messapica: urban entrance characterized by thick wall sections, "latte di calce" (milk of lime) finished; (f) Ceglie Messapica: exemplification of some samples of mural paintings present below the layer of lime. (Pictures: N. Santopuoli, 2012). 
features of urban furnishings of Ceglie Messapica intramural.

\section{Guidelines for Conservative Operations on Architectonic Surfaces of Ceglie Messapica Historic Center}

At the conclusion of the complex research project first phase, Colour Plan (PC) for Ceglie Messapica has been developed with its own "Norme tecniche di attuazione" (Execution technical rules) (NTA). This project aim has been the traditional finishing techniques conservation, the protection and the typological, morphological and aesthetic preservation of historical town architectural and landscape scenes. Besides, guidelines for conservative operations on architectural surfaces have been prepared, defining design methods for surfaces and facade elements operations, provided on historic center and on the adjacent urban area with environmental interest. Specific rules, policies, methodologies and colors to preserve and restore have been defined for every intervention.

Guidelines have been drawn up in the belief that it was necessary to establish a recovery virtuous process of the town and its countryside, through architecture minor reuse.

The control of proposed interventions quality and compatibility with the "image conservation" of "Terra" district monumental scenes can increase architectural heritage economic value, if conducted according to restoration principles.

The discipline introduced by P.C. is useful and necessary, first of all as a methodological proposal disciplinary frame of reference but also to avoid further disruptions and to coordinate, plan, control, assess, and monitor. When it's necessary, guidelines are useful to correct and rectify restoration processes, reducing them into proper method tracks, encouraging and promoting all correct virtuous forms of use, re-use and historic town image conservation.

Summarizing, guidelines drawn up within this research project has as main purposes:

1) the conservation of architectural material heritage made of stone, eventually pigmented lime, earth and tiles, complemented by active and passive process of energetic efficiency improvement.

2) the surface treatments and "patina" conservation of every ancient building, justifying their preservation because these elements and materials characterize both town intra moenia image and agricultural landscape, peri-urban gardens and downstream oak vallonea forests extra moenia view. These elements are indeed bearers of historic signs and stratifications.

3) the circulation and sharing of technical and practical knowledge acquired, constructive-maintenance good practices, in relation to scientific studies made and activities developed in pilot-building sites;

4) the indication of intervention rational and critical method, based on the local architecture e monuments history study, as a preparatory operation to relevant legislative tools development, directed to preservation of historic minor urban and extra-urban heritage.

\section{From the Critical-Conservative Restoration to the Energetic Efficiency Improvement Promotion in Alto Salento Stone Architectures}

Architecture and building techniques history teaches that every civilization has always used local materials that subsoil has offered with their chemical-physical-mechanical properties. In this way, local construction techniques were born, refined over centuries reiterating long-lasting building systems and improving structural, hygrothermal and aesthetic features.

This process, promoted by every "building society", found in Salento a successful answer in the wise use of good lime, in pre-classical age already produced in situ. Over centuries it has been found that slaked lime is valuable material for many technical-constructive uses: it's an excellent surface finishing, hygenic, and easy to spread with a brush, it can be characterized with pigments and create a particular masonry system with the stone substrate because of its compatibility. This construction technique, already known as "a secco" (dry wall) is unique in its kind, cheap and, above all, very efficient from the energetic point of view, because of the particular installation mode of each stone element, covered with thin "latte di calce" (milk of lime) layers.

Starting from this prior knowledge, a historical-critical method to recognize lime surface treatments on Ceglie historic building fabric has been developed. It has been aimed to ensuring the conservation of its special aesthetic and historic characters and excellent thermal-energetic answers.

The project results, carried out from experiments realized for years in building site, allowed the development of the first Colour Plan in which critical-conservative restoration promote passive energetic efficiency improve- 
ment of ancient buildings. This can be done through traditional constructive features preservation. The PC has a specific regulation for its execution, which is divide into two parts. The "Norme tecniche di attuazione" (Execution technical rules) (NTA), that govern all critical building restoration and facade intervention, integrating and substituting PF and current NTA articles, for what is not compatible; the "Restoration guideline" (LGR) that direct methods, techniques and materials to be used in facade and surfaces restoration interventions in private and public contexts. The references are the most recent methods and principles, in respect of "UniNorMal" recommendations, Restoration Charters and local historic architecture specificities.

The regulations and intervention criteria are included in an interdisciplinary research program: here, the energetic-environmental aspects, based on bio-sustainability, energetic efficiency and energy saving, are unavoidably combined to critical-conservative integrated restoration founding principles.

This is achieved by preserving the traditional features of the building and improving thermal-energetic figures at systems and functional level. The critical-conservative restoration addresses the passive ventilation, heating and lighting improvement by 1) exploiting specific morphological details of the building; 2) reducing the incoming energy requirements; 3) minimizing winter thermal dissipation and maximizing the summer one; 4) integrating renewable energy systems; 5) using durable materials from waste disposal recycling; 6) grounding management and maintenance on LCCA [11].

\section{Experimental Researches about Microclimate Study via Computational Fluid Dynamics (CFD) and Joint Exploitation of Thermography and 3D Laser Scanning}

Moreover, we want to underline that in recent years Computational Fluid Dynamics (CFD) has become a common tool in buildings design [12]. Many examples can be found in the literature where CFD has been applied to several design topics such as indoor ventilation and thermal comfort. Most of research efforts have been directed towards the improvement of new buildings architecture. Nevertheless, the analysis of existing monumental buildings has also gained popularity. For example, in a paper in preparation [13], a numerical simulation of flow and temperature fields is developed in the Church of the Nativity located in Bethlehem [14], which is one of the oldest yet continuously operating churches in the world. The computations objective is to examine the impact of windows opening on thermal equilibrium within the church, which may represent a simple but effective strategy to improve the thermal comfort during visiting hours [15]: among the results, note in Figure 3, the contours of static temperature on the horizontal plane located $1.5 \mathrm{~m}$ off the ground: top, closed setup, bottom, opened setup.

Nowadays, the use of thermography represents a widely used non destructive testing tool in many application fields, for example, industrial and civil engineering, cultural heritage, medicine and so on. In fact, infrared thermography systems are able to detect subsurface irregularities and material characteristics, according to surface temperature, but in many situations, the results are only of qualitative type. In order to overcome this trouble, another promising research field is related to the definition of a 3D thermogram [16] in other words, object geometrical information and its thermal properties, coming from a thermographic inspection, are combined in order to have a temperature value for each recognizable point (this result can be obtained in several ways, with a different accuracy degree). In addition, geometrical data, acquired, for example, by means of laser scanner, are also used to normalize temperature values and make thermal data independent from thermal-camera
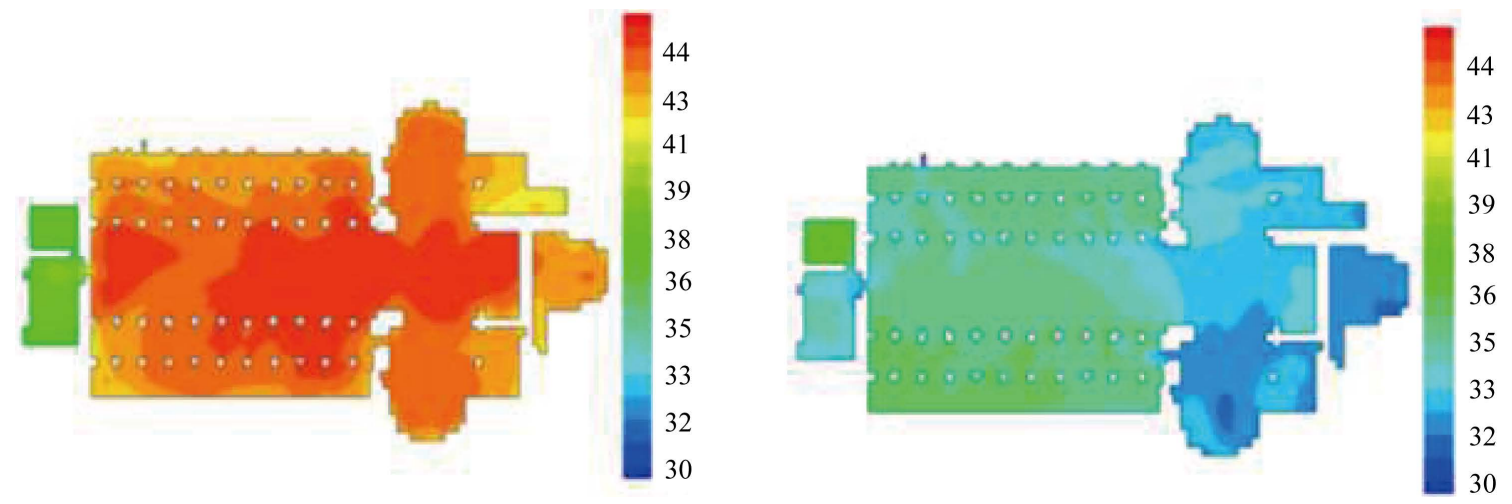

Figure 3. Church of the Nativity located in Bethlehem, contours of static temperature $\left({ }^{\circ} \mathrm{C}\right)$ on the horizontal plane located $1.5 \mathrm{~m}$ off the ground: left, closed setup, right, opened setup. 
point of view (the last goal is more difficult to completely realize, since information related to thermal-camera calibration are necessary, but these ones usually are not publicized by device manufacturers).

\section{References}

[1] Miarelli Mariani, G. (1987) Centri storici, note sul tema. In: Scuola di Specializzazione per lo studio ed il restauro dei monumenti, Strumenti 6, Università degli studi di Roma "La Sapienza”, Roma.

[2] Carbonara, G. (2003) Restauro Architettonico e Impianti, Utet, Torino. In: Carbonara, G., Ed., 2007, Due questioni aperte: strutture e impianti (L'architetto italiano), IV, 26-31.

[3] Carbonara, G. (2004) Atlante del restauro architettonico. Torino, Utet.

[4] de Santoli, L. (2010) La gestione energetica degli edifici. Dario Flaccovio editore, Palermo.

[5] Mora, P. and Mora, L. (1984) Le superfici architettoniche, materiale e colore. In: Bureca, A. and Palandri, G., Eds., Intonaci colore e coloriture nell'edilizia storica. Atti del Convegno, 25-27 October 1984, Bollettino d'Arte, numero speciale, Supplemento 6, Istituto Poligrafico dello Stato, Roma.

[6] Pecoraro, I. (2006, 2010) W la calce! Per una cultura del :minimo intervento”. In: Lo scudo. Mensile cattolico ostunese, LXXX/2006, 3. www.arcidiocesibrindisiostuni.it www.forumcalce.it

[7] Cocchiaro, A. (1998) Messapica Ceglie, Ceglie Messapica.

[8] Carbonara, G. (1999) Restauro Architettonico, Utet, Torino. In: Santopuoli, N. and Seccia, L., Eds., Il rilievo del colore nel campo dei beni culturali, Secondo aggiornamento, UTET, Torino, X, 141-163.

[9] Santopuoli, N., Maietti, F., Alvisi, A. and Sylos Labini, A. (2012) Restauro e colore dei Centri Storici fra identità e salvaguardia. In: Rossi, M. and Siniscalco, A., Eds., Colore e Colorimetria. Contributi Multidisciplinari, Atti del Convegno, Bologna, 13-14 September 2012, Maggioli, Santarcangelo di Romagna (RN), VIII, 229-236.

[10] Pecoraro, I. (2004) Architettura di età moderna in Terra d’Otranto. Tipi murari e meccanismi di collasso, in "Materiali e strutture. Problemi di conservazione”, n.s. II, 3-4/2004, 62-87.

[11] Cumo, F., Piras, G. and Santopuoli, N. (2012) L’ottimizzazione tecnologica ed energetica negli edifici storici. AR Journal, 103, 33-36.

[12] de Santoli, L. and Mariotti, M. (2011) La ventilazione naturale. Dario Flaccovio editore, Palermo.

[13] Rossi, R., Iaccarino, G., Santopuoli, N. and Seccia, L. (In preparation) CFD Modeling of Indoor Ventilation and Thermal Comfort in Monumental Buildings.

[14] Santopuoli, N., Concina, E. and Sarmati, S. (2012) The Conservation of the Church of the Nativity in Bethlehem and the Preliminary Restoration Project of the Decorated Surfaces. Journal of Cultural Heritage, 13, e93-e123. http://dx.doi.org/10.1016/j.culher.2012.10.012

[15] de Santoli, L. and Moncada Lo Giudice, G. (2008) Fondamenti di Sostenibilità Energetico-Ambientale, Roma.

[16] Lucchi, F. (2013) Reverse Engineering Tools: Development and Experimentation of Innovative Methods for Physical and Geometrical Data Integration and Post Processing. Ph.D. Thesis, Bologna University, Bologna. 
Scientific Research Publishing (SCIRP) is one of the largest Open Access journal publishers. It is currently publishing more than 200 open access, online, peer-reviewed journals covering a wide range of academic disciplines. SCIRP serves the worldwide academic communities and contributes to the progress and application of science with its publication.

Other selected journals from SCIRP are listed as below. Submit your manuscript to us via either submit@scirp.org or Online Submission Portal.
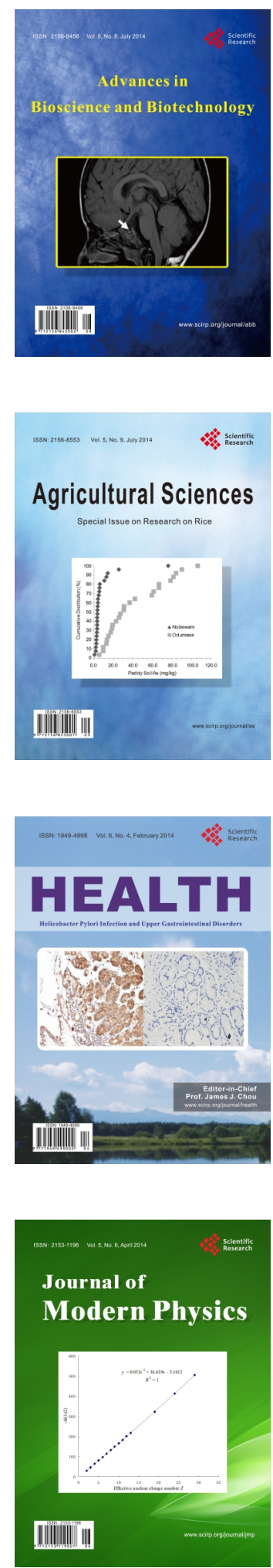
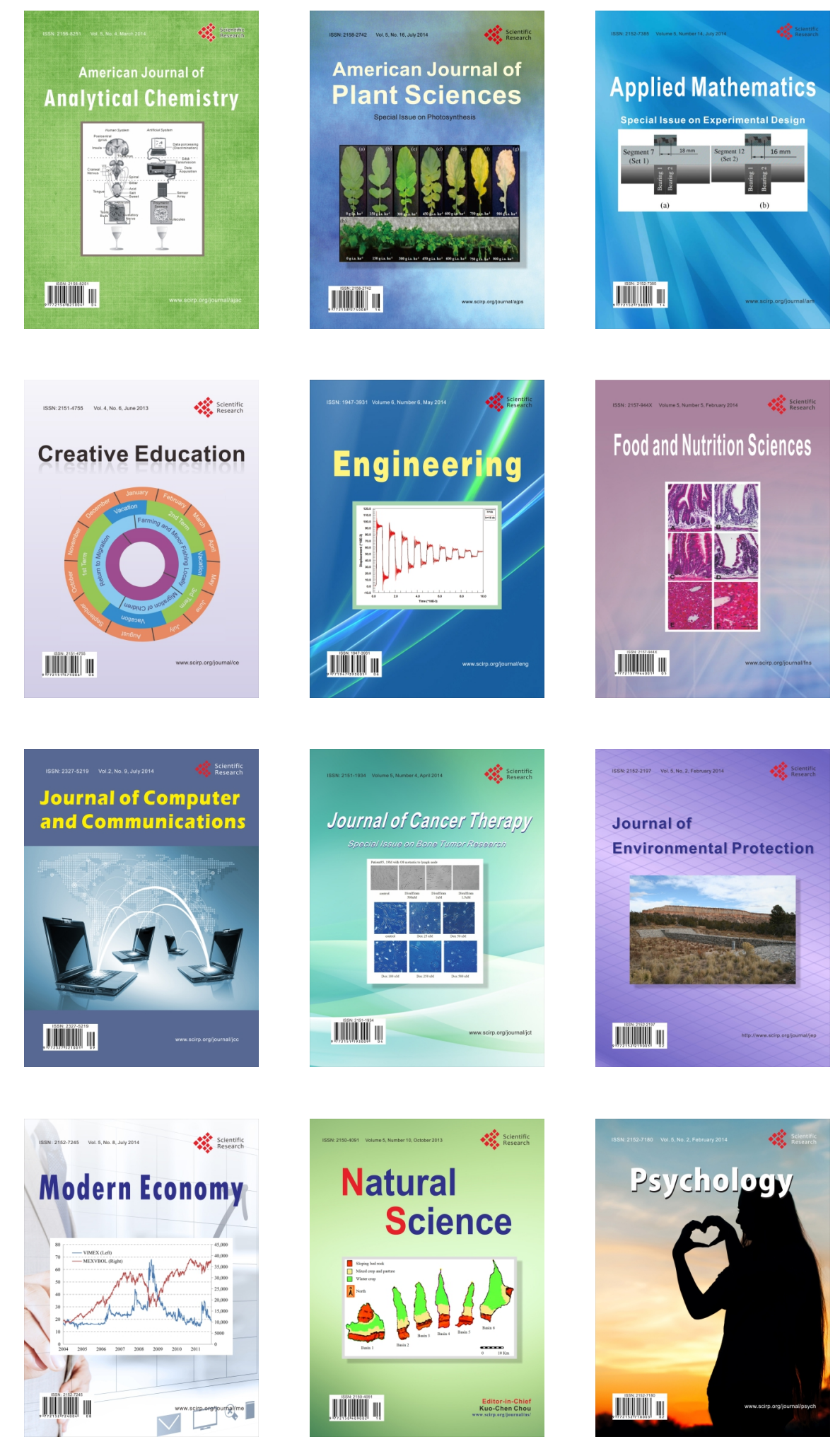